\title{
STRATEGI PENINGKATAN EFEKTIVITAS PENGELOLAAN KAWASAN KONSERVASI TAMAN NASIONAL KARIMUNJAWA
}

\section{STRATEGY FOR IMPROVING THE EFFECTIVENESS OF MANAGEMENT IN THE KARIMUNJAWA NATIONAL PARK CONSERVATION AREA}

\author{
Artika Nanda Magfiroh ${ }^{1 *}$, Zairion ${ }^{2}, \&$ Achmad Fahrudin ${ }^{2}$ \\ ${ }^{1}$ Program Studi Pengelolaan Sumberdaya Pesisir dan Lautan, Sekolah Pascasarjana, \\ IPB University, Bogor, 16680, Indonesia \\ ${ }^{2}$ Departemen Manajemen Sumberdaya Perairan, FPIK, IPB University, Bogor, 16680, Indonesia \\ *E-mail: artika_nanda@apps.ipb.ac.id
}

\begin{abstract}
Karimunjawa National Park (TNKJ) is included in the national action plan for the management of conservation areas in 2018-2025. The objective of this research is to assess the effectiveness of the management of the TNKJ conservation area based on assessment guidelines in Indonesia, then the effective strategic recommendation is obtained for increasing the effectiveness of the management of the TNKJ conservation area. The study were conducted in August-December 2019. The assessment methods were used in this research are a score card for the Management Effectiveness Tracking Tool (METT) guideline, Management Effectiveness Evaluation guidelines for Marine Conservation Areas in Indonesia (COREMAP II-LIPI) and the building block assessment method for the Technical Effectiveness Evaluation guidelines Management of Marine, Coastal and Small Islands Conservation Areas $(E-K K P 3 K)$. The results showed the assessment of the management of the TNKJ conservation area was considered as the most effective based on METT guidelines, COREMAP II-LIPI guidelines and the green status by E-KKP3K guidelines. The analysis is carried out by using the Analytic Network process (ANP) method. The implementation of the zoning system was been the main problem of the TNKJ management. Public and tourist awareness of the risk of waste and environmental damage were being the best solution for increasing the effectiveness of the management of the TNKJ.
\end{abstract}

Keywords: conservation, effectiveness, Karimunjawa, management, strategy

\begin{abstract}
ABSTRAK
Taman Nasional Karimunjawa (TNKJ) masuk dalam rencana aksi nasional pengelolaan kawasan konservasi tahun 2018-2025. Tujuan penelitian adalah mengkaji efektivitas pengelolaan kawasan konservasi TNKJ, sehingga diperoleh rekomendasi strategis yang efektif untuk peningkatan efektivitas pengelolaan kawasan konservasi TNKJ. Penelitian dilaksanakan pada bulan Agustus-Desember 2019. Metode penilaian yang digunakan adalah score card untuk pedoman Management Effectiveness Tracking Tool (METT) dan pedoman Evaluasi Efektivitas Pengelolaan untuk Kawasan Konservasi Laut di Indonesia (COREMAP II-LIPI) serta metode penilaian system blocking untuk pedoman Teknis Evaluasi Efektivitas Pengelolaan Kawasan Konservasi Perairan, Pesisir dan Pulau-Pulau Kecil (EKKP3K). Analisis prioritas strategi peningkatan efektivitas pengelolaan kawasan konservasi TNKJ dilakukan menggunakan metode jejaring analitik (Analytic Network process, ANP). Hasil penelitian menunjukkan bahwa penilaian pengelolaan kawasan konservasi TNKJ dikatakan sangat efektif menurut pedoman METT, efektif menurut pedoman COREMAP II-LIPI dan berstatus hijau menurut pedoman E-KKP3K. Permasalahan prioritas pengelolaan TNKJ adalah implementasi sistem zonasi, sedangkan solusi prioritas untuk meningkatkan efektivitas pengelolaan TNKJ adalah penyadaran masyarakat dan wisatawan terhadap bahaya sampah dan kerusakan lingkungan.
\end{abstract}

Kata kunci: konservasi, efektivitas, Karimunjawa, pengelolaan, strategi 


\section{PENDAHULUAN}

Kawasan konservasi laut adalah kawasan yang berada di pesisir dan laut dengan pembagian wilayah intertidal, subtidal dan kolom air di atasnya dengan cakupan berbagai flora dan fauna yang saling berasosiasi dan memiliki nilai ekologi, ekonomi, sosial dan budaya (Bengen, 2001). Kawasan konservasi memiliki peranan penting bagi keberlanjutan ekosistem dan peningkatan kesejahteraan masyarakat (Leenhardt et al., 2015). Saat ini, kawasan konservasi laut secara umum digunakan sebagai pedoman pengelolaan dan pemanfaatan sumber daya kelautan yang berkelanjutan (Hargreaves-Allen et al., 2011)

Pentingnya kawasan konservasi dalam pembangunan nasional diperkuat dengan Peraturan Presiden Republik Indonesia Nomor 56 Tahun 2019 tentang rencana aksi nasional pengelolaan terpadu taman nasional dan kawasan konservasi perairan nasional tahun 2018-2025. Pasal 2 Perpres tersebut mencakup beberapa hal, diantaranya adalah strategi dalam rencana aksi penguatan kinerja pengelolaan Taman Nasional dan Kawasan Perairan Nasional yang efektif. Menurut Undang-Undang Nomor 5 Tahun 1990 tentang Konservasi Sumber Daya Alam Hayati dan Ekosistemnya, Taman Nasional didefinisikan sebagai kawasan pelestarian alam yang mempunyai ekosistem asli, dikelola dengan sistem zonasi yang dimanfaatkan untuk tujuan penelitian, ilmu pengetahuan, pendidikan, menunjang budidaya, pariwisata, dan rekreasi. Kemenkomaritim (2017) menyebutkan hasil penelitian awal efektivitas pengelolaan dari 7 kawasan Taman Nasional (Kepulauan Seribu, Karimunjawa, Teluk Cendrawasih, Taka Bonerate, Kepulauan Togean, Wakatobi, dan Bunaken) rata-rata adalah $69 \%$. Nilai tersebut berada di bawah indikator kinerja program Konservasi dan Sumber Daya Alam Ekosistem (KSDAE) tahun 2015-2019 dengan nilai indeks efektivitas pengelolaan kawasan konservasi kategori baik sebesar 70\%. Penguatan kinerja pengelolaan kawasan konservasi yang efektif menurut Pelletier et al. (2005) dapat dicapai dengan mengukur parameter keberhasilan pengelolaan kawasan konservasi dengan tiga sudut pandang penting, yakni ekologi, ekonomi, dan sosial.

Rencana aksi menurut Peraturan Presiden Republik Indonesia Nomor 56 Tahun 2019 dilaksanakan di 17 lokasi yang terdiri dari 7 Taman Nasional dan 10 Kawasan Konservasi Perairan Nasional. Taman Nasional yang masuk dalam rencana aksi tersebut salah satunya adalah Taman Nasional Karimunjawa (TNKJ). Demi terciptanya pengelolaan kawasan konservasi yang efektif dan memberikan manfaat bagi masyarakat dan lingkungan, perlu adanya pedoman penilaian pengelolaan kawasan konservasi yang dapat digunakan untuk mengetahui sejauh mana efektivitas pengelolaan kawasan konservasi yang dilakukan. Indonesia memiliki beberapa panduan penilaian efektivitas pengelolaan kawasan konservasi dari instansi dan kementerian terkait. Selama kurun waktu 2010 hingga 2019, terdapat sedikitnya tiga panduan penilaian efektivitas pengelolaan kawasan konservasi. Direktorat Jenderal Konservasi Sumber Daya Alam dan Ekosistem Kementerian Lingkungan hidup dan Kehutanan mengeluarkan pedoman penilaian METT (Management Effectiveness Tracking Tool) pada tahun 2015. Direktorat Jenderal Pengelolaan Ruang Laut Kementerian Kelautan dan Perikanan mengeluarkan Pedoman Teknis Evaluasi Efektivitas Pengelolaan Kawasan Konservasi Perairan, Pesisir dan Pulau-Pulau Kecil (EKKP3K) pada tahun 2012. COREMAP IILIPI mengeluarkan Panduan Evaluasi Efektivitas Pengelolaan untuk Kawasan Konservasi Laut di Indonesia pada tahun 2010.

Penentuan pedoman penilaian efektivitas kawasan konservasi yang tepat sesuai paradigma kawasan konservasi dapat menunjang keberhasilan pengelolaan 
kawasan konservasi yang memberikan manfaat bagi masyarakat. Faktor penentu keberhasilan dan permasalahan pencapaian tujuan pengelolaan kawasan konservasi dapat terlihat dari hasil penilaian efektivitas pengelolaan kawasan konservasi. Teridentifikasinya permasalahan kawasan konservasi dapat menjadi pedoman pembuatan strategi pengelolaan demi meningkatkan efektivitas pengelolaan kawasan konservasi yang memberikan manfaat ekologi, ekonomi dan sosial. Manfaat kawasan konservasi menurut Firdaus \& Sari (2010) dibedakan menjadi manfaat yang dapat diukur (tangible) dan manfaat yang tidak diukur (intangible). Manfaat tersebut dikategorikan berdasarkan aspek ekologi, ekonomi dan sosial yang secara umum dirasakan dalam jangka panjang. Berdasarkan hal tersebut, penelitian ini bertujuan untuk mengkaji efektivitas pengelolaan kawasan konservasi TNKJ berdasarkan pedoman penilaian yang ada di Indonesia, sehingga menjadi rekomendasi yang strategis dan efektif untuk peningkatan efektivitas pengelolaan kawasan konservasi TNKJ.

\section{METODE PENELITIAN}

\subsection{Waktu dan Lokasi Kegiatan}

Penelitian ini dilaksanakan pada bulan Agustus-Desember 2019 dengan lokasi penelitian di kawasan konservasi Taman Nasional Karimunjawa (TNKJ) yang terletak di Kabupaten Jepara, Jawa Tengah. Secara geografis TNKJ berada pada koordinat 5'40'39" $-5^{\circ} 55^{\prime} 00^{\prime \prime}$ LS dan $110^{\circ} 05^{\prime}$ '57'110³1' 15” BT (Figure 1).

\subsection{Metode Pengumpulan Data}

Data yang dikumpulkan dalam penelitian ini adalah data primer dan data sekunder. Pengumpulan data primer dilakukan dengan cara observasi, wawancara individual secara mendalam terhadap responden terkait aktor pengelolaan kawasan konservasi, diskusi informal dan kajian literatur. Data tersebut digunakan untuk menjawab pertanyaan elemen kelembagaan dalam pedoman penilaian METT, E-KKP3K, dan COREMAP II - LIPI.

Pendekatan berdasarkan pendapat pakar dapat digunakan dalam pencapaian

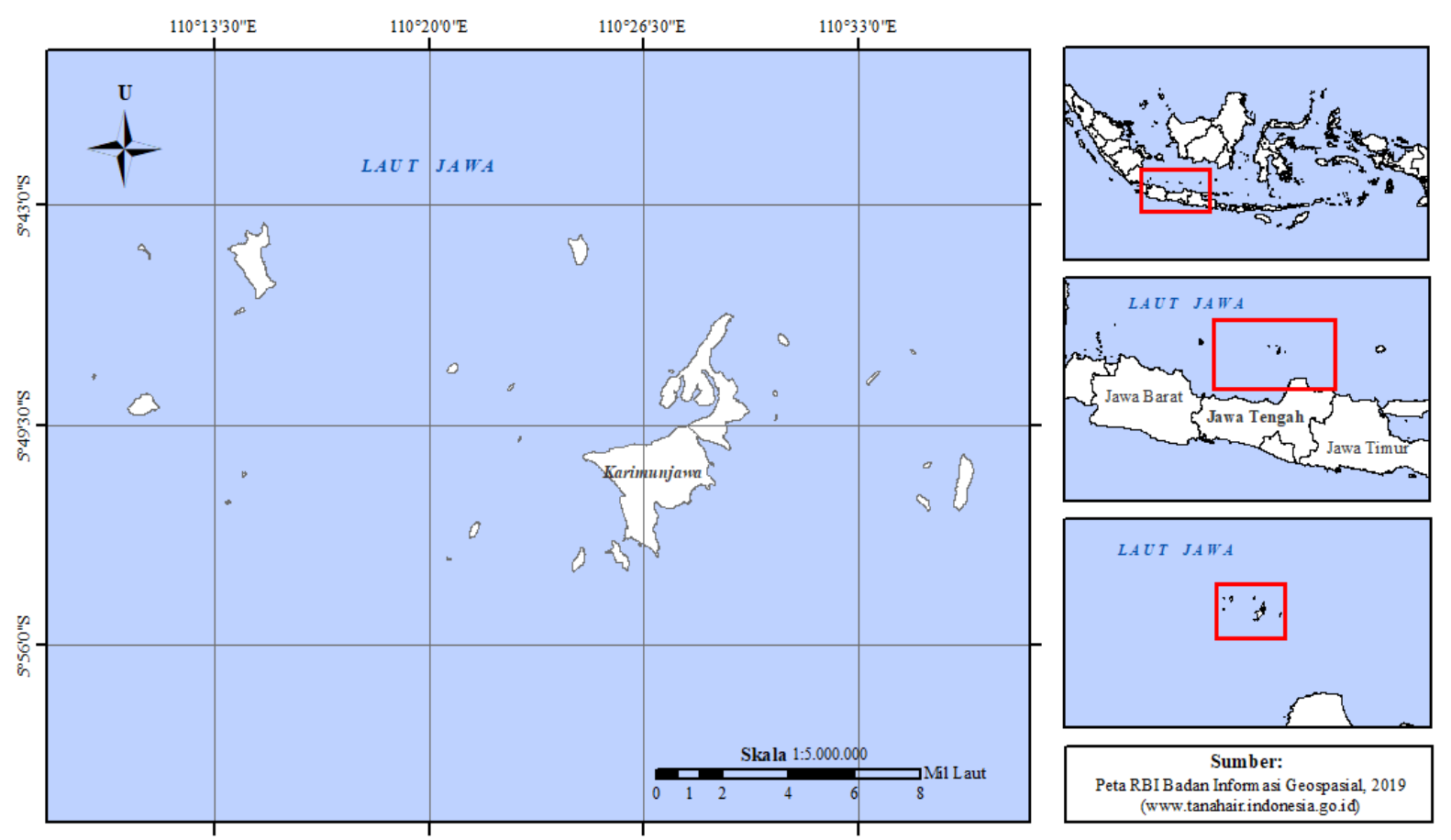

Figure 1. The conservation area of Taman Nasional Karimun Jawa. 
pengelolaan yang adaptif (Mittermeier et al., 1995). Responden terkait aktor dalam pengelolaan kawasan konservasi TNKJ ditentukan dengan teknik penarikan contoh nonprobabilistik, yaitu purposive sampling dan snowball effect. Hal tersebut bertujuan untuk menghimpun informasi sebanyak-banyaknya terkait pengelolaan kawasan konservasi TNKJ (Kerlingeer \& Lee, 2000). Selanjutnya, data sekunder digunakan untuk menjawab pertanyaan elemen ekologi, sosial dan ekonomi dalam pedoman penilaian METT, E-KKP3K, dan COREMAP II-LIPI. Data sekunder ini didapat dari data yang berbentuk dokumen, laporan dan publikasi lainnya yang terkait dengan hasil penelitian berupa data laporan ekologi dari Wildlife Conservation Society (WCS), laporan capaian renstra tahun 2015-2019 Balai Taman Nasional Karimunjawa, laporan kinerja Balai Taman Nasional Karimunjawa tahun 2019 dan statistik Balai Taman Nasional Karimunjawa tahun 2019.

\subsection{Analisis Data}

Data primer dan sekunder yang diperoleh untuk menghitung nilai efektivitas pengelolaan kawasan konservasi TNKJ dalam penelitian ini dianalisis secara kualitatif-kuantitatif untuk menggambarkan secara sistematis mengenai fakta dan hubungan antara fenomena yang diteliti (Juliyanto et al., 2019). Jumlah individu yang menjadi responden pakar penentuan skala prioritas strategi peningkatan efektivitas pengelolaan kawasan konservasi TNKJ adalah lima pakar (Hora, 2009). Selanjutnya data tersebut diolah sesuai dengan pedoman penilaian efektivitas pengelolaan kawasan konservasi yang ada di Indonesia. Data yang dikumpulkan kemudian diolah menggunakan metode Analytic Network Process (ANP), di input melalui software superdecision 2.6 dan diproses guna menghasilkan output berbentuk prioritas dan supermatriks. Hasil dari setiap responden akan di input pada jaringan ANP tersendiri untuk membantu penentuan permasalahan dan strategi pengelolaan kawa- san konservasi TNKJ yang efektif. Analisis masing-masing pedoman secara lebih lengkap sebagai berikut:

\subsubsection{METT (Management Effectiveness Tracking Tool) oleh Kementerian Lingkungan Hidup dan Kehutanan Tahun 2017}

Secara resmi Indonesia menggunakan metode METT sebagai kebijakan nasional dan menjadi salah satu indikator kinerja (KLHK, 2015). Perhitungan METT untuk kawasan konservasi perairan dilakukan menggunakan Score Card to Achieving Management Effectiveness Goals for Marine Protected Area yang merupakan adopsi dari METT. Pengisian kartu skor oleh responden di input dengan memindahkan skor masingmasing pertanyaan ke dalam template Microsoft Excel. Data yang diperoleh pada kartu skor dianalisis secara kuantitatif dengan menghitung persentase nilai untuk setiap elemen dengan rumus:

Nilai akhir $=$
$\frac{\text { Total Skor }}{\text { Nilai Maksimum }} \times 100 \%$

\subsubsection{Pedoman Teknis Evaluasi Efektivitas Pengelolaan Kawasan Konservasi Perairan, Pesisir dan Pulau-Pulau Kecil (E-KKP3K) Tahun 2012}

Perangkat E-KKP3K digunakan untuk melakukan evaluasi terhadap efektivitas pengelolaan kawasan konservasi yang meliputi kawasan konservasi perairan dan kawasan di wilayah pesisir dan pulaupulau kecil di bawah naungan Kementerian Kelautan dan Perikanan sejak tahun 2012 (KKP, 2013). Perhitungan evaluasi berdasarkan buku E-KKP3K dilakukan dengan cara menjawab pertanyaan yang tertera pada software E-KKP3K disertai bukti lampiran pendukung. Data yang diperoleh pada kartu skor dianalisis secara kuantitatif dengan menghitung persentase nilai untuk setiap elemen dengan rumus: 
Capaian $(\%)=\frac{\text { Jumlah pertanyaan yang mendapat jawaban " } \mathrm{Ya} \text { " }}{\text { Jumlah pertanyaan pada peringkat yang dînilai }} \times 100 \%$

\subsubsection{Panduan Evaluasi Efektivitas Pengelolaan untuk Kawasan \\ Konservasi Laut di Indonesia CRITC COREMAP (Coral Reef Rehabilitation and Management Program) II-LIPI, 2010)}

Tujuan dari kegiatan penyusunan panduan evaluasi efektivitas pengelolaan untuk kawasan konservasi laut di Indonesia oleh COREMAP II-LIPI adalah untuk mendapatkan informasi mengenai pengelolaan Kawasan Konservasi Laut (KKL) dan menyusun protokol/panduan evaluasi efektivitas pengelolaan KKL (Susetiono et al., 2010). Perhitungan menggunakan pedoman dari COREMAP II-LIPI dilakukan dengan mengisi skor berdasarkan hasil jawaban dari informan terkait pengelolaan kawasan konservasi. Hasil pengisian kartu skor oleh responden di input dengan memindahkan skor masing-masing pertanyaan ke dalam template Microsoft Excel. Data yang diperoleh pada kartu skor dianalisis secara kuantitatif dengan menghitung persentase nilai untuk setiap elemen dengan rumus:

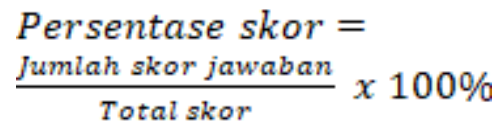

\subsubsection{Analytic Network Process (ANP)}

ANP merupakan teori pengukuran relatif yang dapat digunakan dalam penurunan rasio prioritas komposit dari skala rasio individu yang mencerminkan pengukuran relatif dari pengaruh elemen-elemen yang saling berinteraksi (Saaty, 2005). Perhitungan dengan metode ANP dilakukan dengan memberikan nilai keterkaitan yang diberikan secara relatif. Tahap yang dilakukan dalam metode ANP, yaitu:

\subsubsection{Konstruksi Model}

Konstruksi model ANP dibuat berdasarkan studi pustaka secara teori maupun empiris. Selain itu, konstruksi model ANP dibuat dengan mengajukan pertanyaan pada ahli pengelolaan kawasan konservasi TNKJ dan melakukan wawancara secara mendalam (indepth interview) untuk mengetahui permasalahan-permasalahan yang terjadi pada pengelolaan kawasan konservasi TNKJ.

\subsubsection{Kuantifikasi Model}

Kuantifikasi model ANP merupakan tahap penyusunan kuesioner yang berupa pairwise comparison (pembandingan pasangan) antara elemen dalam cluster. Tahap penyusunan kuesioner ini dilakukan setelah melewati tahapan konstruksi model dan validasi model ANP dengan tujuan mengetahui pengaruh dominan antar elemen dan mengetahui perbedaan melalui skala numerik 1-9.

\subsubsection{Sintesis dan Analisis Hasil}

Analisis hasil kuesioner yang telah diisi oleh informan ahli tekait pengelolaan kawasan konservasi TNKJ di input menggunakan software superdecision, kemudian dilanjutkan dengan menghitung nilai Kendall's Coefficient of Concordance yang merupakan alat ukur perhitungan rater agreement dengan menggunakan bantuan Microsoft Excel.

Ascarya (2010) menyebutkan sintesis pada perhitungan metode ANP dapat dilakukan menggunakan rater agreement yang dapat digunakan untuk menunjukkan tingkat persetujuan para responden (R1-Rn) terhadap suatu permasalahan dalam satu cluster. Alat yang berfungsi untuk mengukur rater agreement adalah Kendall's Coefficient of Concordance (W; $0<\mathrm{W} \leq 1)$. W= 1 menunjukkan kesesuaian yang sempurna. Tahapan untuk menghitung Kendall's (W) adalah:

Menghitung total jumlah peringkat tiap masing-masing cluster:

$X a=(R 1+R 2+\cdots+R n)$ 
Menghitung nilai rata-rata (U) dari total peringkat tiap cluster:

$U=\frac{X a+X b+\cdots+X z}{z}$

Menghitung nilai jumlah kuadrat deviasi (S), dihitung dengan formula:

$S=$

$(R 1-u)^{2}+(R 2-u)^{2}+\cdots+(R n-u)^{2}$

Menghitung nilai maksimal kuadrat deviasi (Max S), dihitung dengan formula:

$\operatorname{Max} S=$

$(n-u)^{2}+(2 n-u)^{2}+\cdots+(Z n-u)^{2}$

Langkah terakhir menentukan nilai Kendall's $\mathrm{W}$ dalam perhitungan rater agreement dengan formula:

$W=\frac{s}{\operatorname{Max} S}$

Keterangan: $\mathrm{X}=$ Jumlah tiap cluster; $\mathrm{R}=$ Bobot ranking tiap responden; $\mathrm{n}=\mathrm{Jumlah}$ responden; $\mathrm{z}=$ Banyaknya cluster; $\mathrm{U}=$ Ratarata nilai total pada tiap cluster; $\mathrm{S}=$ Nilai jumlah kuadrat deviasi; Max $\mathrm{S}=$ Nilai maksimal kuadrat deviasi; $\mathrm{W}=$ Rater of Agreement.

\section{HASIL DAN PEMBAHASAN}

\subsection{Analisis Efektivitas Pengelolaan dengan METT}

Evaluasi efektivitas pengelolaan kawasan konservasi TNKJ merupakan kegiatan rutin tahunan dari Balai TNKJ yang dilakukan oleh pihak balai dengan menggunakan pedoman METT. Pedoman penilaian efektivitas kawasan konservasi yang dilakukan dengan pedoman METT memiliki sistem penilaian score card. Penilaian pengelolaan kawasan konservasi yang dilakukan dengan pedoman METT dibagi menjadi 6 (enam) komponen pengelolaan, yakni konteks, perencanaan, input, proses, output dan outcome.

Hasil olahan yang dilakukan oleh pihak Balai TNKJ pada tahun 2019 menunjukan bahwa pengelolaan kawasan konservasi TNKJ secara keseluruhan memiliki nilai $78 \%$ dengan nilai dari ke-enam komponen yang berbeda (Figure 2). Secara umum, fokus evaluasi pada tiap komponen berbeda. Komponen konteks berfokus pada status, komponen perencanaan berfokus pada kesesuaian, komponen input berfokus pada sumber daya, komponen proses berfokus pada efisiensi dan kesesuaian, sedangkan komponen output berfokus pada efektivitas serta komponen outcome berfokus pada efektivitas dan kesesuaian.

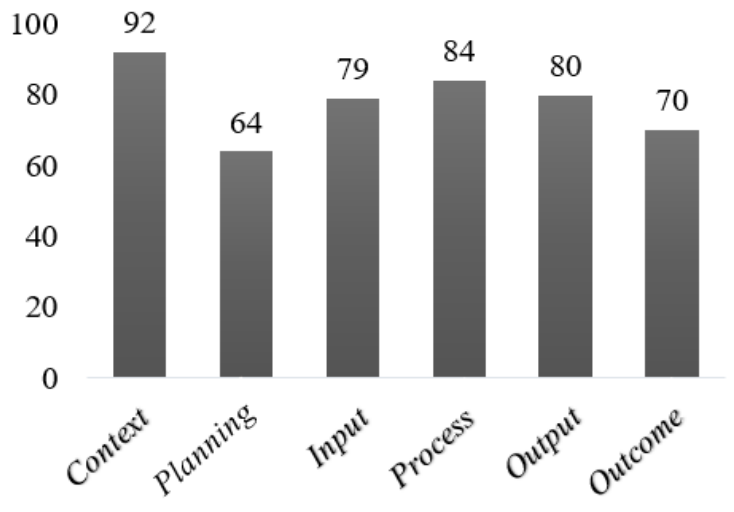

Figure 2. The Results Assessment of The Management of The TNKJ Conservation Area Based on METT Guidelines (\%).

Hasil penilaian yang diperoleh menunjukkan elemen perencanaan dan outcome memiliki nilai yang lebih rendah dibandingkan elemen lainnya. Hal ini terkait dengan beberapa indikator penilaian yang belum dapat terjawab dengan baik. Indikator tersebut dipetakan menjadi isu prioritas. BTNKJ (2019) menyebutkan isu prioritas komponen perencanaan adalah adanya kesenjangan skema penganggaran dengan Rencana Pengelolaan Jangka Panjang (RPJP) BTNKJ Tahun 2018-2027. Sementara itu, isu prioritas komponen outcome adalah upaya 
restorasi kondisi sumber daya alam perlu dilakukan terutama ekosistem terumbu karang pada zona pemanfaatan.

Pedoman METT yang digunakan oleh KLHK perkembangannya dirasakan perlu melibatkan pihak-pihak lain yang terkait dengan pengelolaan untuk memberikan hasil yang lebih akurat dan objektif. Penilaian efektivitas harus menjadi bagian dari siklus manajemen yang efektif terkait dengan nilai, tujuan, dan kebijakan yang ditetapkan. KLHK (2015) menyebutkan Perangkat METT dirasakan perlu untuk dilangkapi dengan beberapa informasi yang diperlukan dalam penerapan di Indonesia. Selain itu, metode penilaian score card tidak banyak menggambarkan pencapaian dari tujuan pengelolaan kawasan konservasi laut.

\subsection{Analisis Efektivitas Pengelolaan dengan E-KKP3K}

E-KKP3K merupakan pedoman penilaian efektivitas kawasan konservasi di Indonesia yang digunakan oleh Kementerian Kelautan dan Perikanan (KKP). E-KKP3K telah memiliki perangkat lunak (software) tersendiri dalam penentukan penilaian suatu kawasan konservasi yang dapat di download pada website KKP. Hal ini memudahkan para pengelola dan pihak yang berkepentingan dalam melakukan penilaian efektivitas kawasan konservasi. Pedoman penilaian efektivitas kawasan konservasi yang dilakukan dengan menggunakan E-KKP3K memiliki sistem penilaian building block, yang mana kriteria efektivitas kawasan konservasi dibagi menjadi 5 (lima) peringkat yakni merah, kuning, hijau, biru dan emas. Hasil olahan data untuk efektivitas pengelolaan kawasan konservasi TNKJ menunjukkan pada peringkat hijau yang berarti kawasan tersebut merupakan kawasan konservasi yang dikelola secara minimum (Figure 3).

Setiap peringkat pada E-KKP3K memiliki arti yang berbeda. Peringkat merah berarti kawasan konservasi merupakan kawasan konservasi yang diinisiasi. Peringkat kuning memiliki arti suatu kawasan konservasi merupakan kawasan konservasi yang didirikan. Peringkat hijau berarti kawasan konservasi tersebut merupakan kawasan konservasi yang dikelola secara minimum. Peringkat biru memiliki arti bahwa kawasan konservasi yang dikelola secara optimum. Sementara itu, peringkat emas memiliki arti status kawasan konservasi tersebut adalah kawasan konservasi yang mandiri.

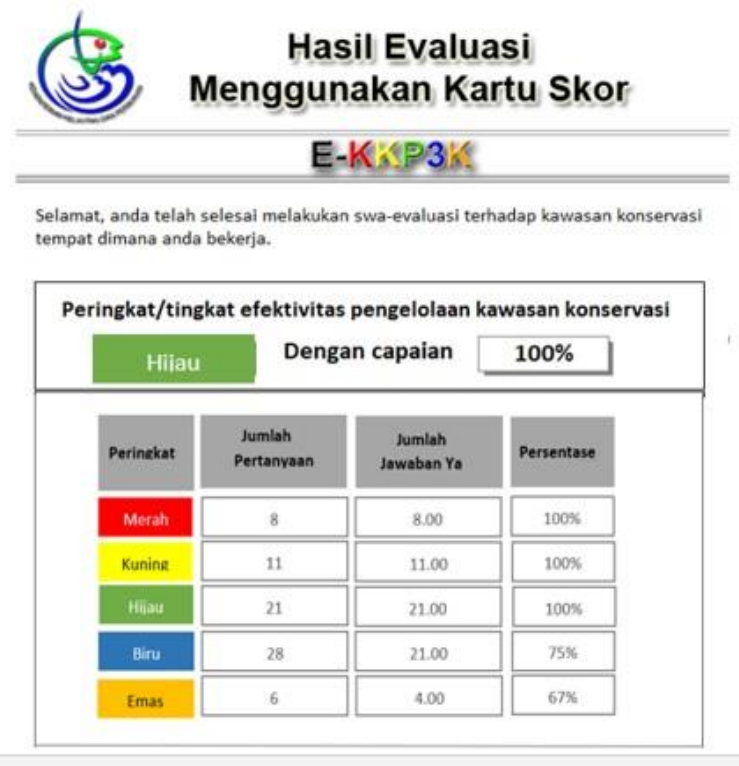

Figure 3. The Results Assessment of The Management of The TNKJ Conservation Area Based on E-KKP3K Guidelines.

Isu prioritas status biru yang tidak mencapai $100 \%$ disebabkan karena jumlah tangkapan nelayan dan jumlah spesies target non-ikan di zona perikanan berkelanjutan/ zona pemanfaatan terbatas tidak memiliki jumlah yang tetap ataupun meningkat. Kondisi ini mengakibatkan ketidakstabilan harga jual hasil perikanan. Selain itu, belum adanya pendataan lengkap terkait kualitas perairan di seluruh wilayah TNKJ menyebabkan degradasi ekosistem belum dapat diidentifikasi dengan baik. Isu prioritas status emas yang tidak mencapai 100\% disebabkan karena kemitraan dengan pemangku kepentingan belum sepenuhnya berjalan baik dan 
berdampak positif. Kurangnya koordinasi antar lembaga menjadi penyebab belum optimalnya kerjasama yang dilakukan di wilayah TNKJ.

KKP (2012) menyebutkan E-KKP3K menganut prinsip "membangun tumpukan balok" (building block). Prinsip ini mempersyaratkan bahwa peringkat selanjut-nya tidak mungkin dapat dicapai bila kegiatankegiatan pada peringkat sebelumnya belum selesai dilaksanakan atau mendapat hasil $100 \%$. Dengan adanya hal tersebut mengakibatkan meskipun peringkat lain mendapat nilai baik, nilai yang diperoleh tersebut tidak dapat digunakan dalam penentuan peringkat status pengelolaan.

\subsection{Analisis Efektivitas Pengelolaan dengan Pedoman COREMAP II- LIPI}

Pedoman penilaian efektivitas pengelolaan kawasan konservasi COREMAP IILIPI lebih unggul pada penilaian bab ekologi jika dibandingkan dengan pedoman penilaian menurut International Union for Conservation of Nature (IUCN) yang ada di Indonesia hingga tahun 2019. Hal ini disebabkan karena penyajian pertanyaan bab ekologi pada pedoman ini lebih spesifik. Penilaian pengelolaan kawasan konservasi yang dilakukan dengan pedoman COREMAP II-LIPI dibagi menjadi 6 (enam) komponen pengelolaan, yakni latar belakang, perencanaan, kebutuhan, pelaksanaan, keluaran dan pencapaian.

Berdasarkan hasil olahan yang dilakukan, efektivitas pengelolaan kawasan konservasi TNKJ menurut pedoman COREMAP II-LIPI secara total memiliki nilai $71 \%$ dan memiliki enam komponen dengan nilai berbeda (Figure 4). Secara umum, fokus pertanyaan evaluasi pada tiap komponen berbeda. Komponen latar belakang berfokus pada kondisi/status Kawasan Konservasi Laut (KKL), komponen perencanaan berfokus pada ketepatan dari rancangan dan perencanaan, komponen kebutuhan berfokus pada kebutuhan yang diperlukan dalam pelaksanaan pengelolaan, komponen pelaksanaan berfokus pada pelaksanaan kegiatan pengelolaan, sedangkan komponen keluaran berfokus pada perkembangan KKL dan hasil kegiatan pelaksanaan yang dilakukan pada tahap-tahap sebelumnya dan komponen pencapaian berfokus pada dampak dari kegiatan pengelolaan serta pencapaian tujuan dari pengelolaan.

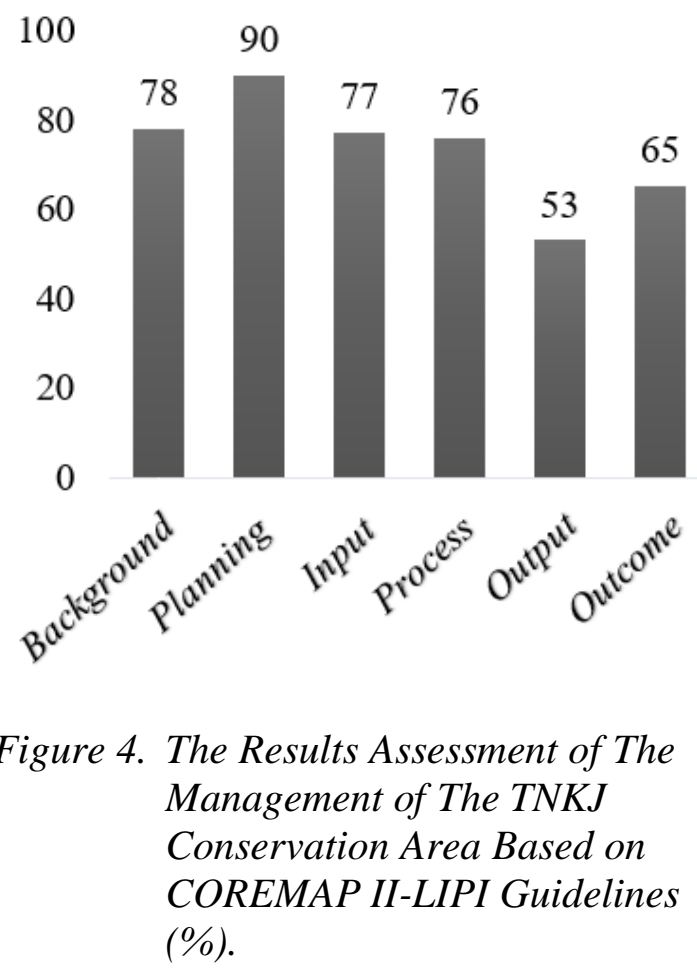

Hasil penilaian yang diperoleh menunjukkan elemen keluaran dan pencapaian memiliki nilai yang lebih rendah dibandingkan elemen lainnya. Hal ini terkait dengan beberapa indikator penilaian yang belum dapat terjawab dengan baik. Indikator tersebut dipetakan menjadi isu prioritas. Isu prioritas komponen keluaran adalah belum adanya peningkatan nilai konservasi serta belum adanya peningkatan kesadaran dan kepedulian pemangku kepentingan terhadap pengelolaan kawasan konservasi TNKJ. Sementara itu, isu prioritas komponen pencapaian adalah belum optimalnya analisis ancaman dan konflik dari dampak kegiatan pengelolaan kawasan konservasi serta masih adanya konflik di sektor pelayaran, peman- 
faatan sumber daya, dan sumber daya.

Panduan dari COREMAP II-LIPI bukan merupakan pedoman resmi yang digunakan oleh instansi terkait dalam mengelola kawasan konservasi laut. Hal ini dikarenakan pedoman COREMAP II-LIPI merupakan salah satu panduan evaluasi pengelolaan kawasan konservasi laut yang dilakukan secara parsial dalam kerangka kegiatan dari pemenuhan program kerjasama antara COREMAP II dengan LIPI.

\subsection{Status Efektivitas Pengelolaan Kawasan Konservasi Taman Nasional Karimunjawa}

Nilai indeks efektivitas pengelolaan kawasan konservasi modifikasi Pitchter (1999) dibagi menjadi 4 (empat), yakni kurang efektif (0-25\%), cukup efektif (26$50 \%)$, efektif $(51-75 \%)$ dan sangat efektif (75-100\%). Berdasarkan hasil yang diperoleh menunjukan bahwa pengelolaan kawasan konservasi TNKJ dikatakan sangat efektif menurut pedoman METT yang dihitung oleh pihak Balai TNKJ dengan hasil penilaian adalah 78\%. Akan tetapi status efektivitas pengelolaan kawasan konservasi menjadi efektif apabila dihitung dengan metode COREMAP II-LIPI dengan hasil penilaian $71 \%$. Berbeda dengan penilaian efektivitas pengelolaan menggunakan metode METT dan COREMAP II-LIPI, penilaian status efektivitas pengelolaan kawasan konservasi TNKJ menggunakan metode E-KKP3K menunjukkan pada peringkat hijau yang berarti kawasan tersebut merupakan kawasan konservasi yang dikelola secara minimum. Hasil penilaian yang menunjukkan pertanyaan pada peringkat hijau dapat terjawab $100 \%$, dengan hal tersebut berarti kawasan konservasi TNKJ telah dikelola secara efektif.

Parameter keberhasilan pengelolaan kawasan konservasi dapat dilihat dari pencapaian tujuan dibentuknya kawasan konservasi tersebut. Rencana Strategis Balai TNKJ tahun 2015-2019 sesuai dengan tujuan pembangunan Kementerian Lingkungan Hidup dan Kehutanan tahun 2015-2019 yaitu memastikan kondisi lingkungan berada pada toleransi yang dibutuhkan untuk kehidupan manusia dan sumber daya berada pada rentang populasi yang aman, serta secara paralel meningkatkan kemampuan sumber daya alam untuk memberikan sumbangan pada perekonomian nasional. Salah satu ekosistem penting yang menunjang keberhasilan pengelolaan kawasan konservasi adalah terumbu karang. Cahyani et al. (2018) menyebutkan terumbu karang merupakan salah satu ekosistem laut yang memiliki nilai penting bagi masyarakat pesisir dan keberadaannya sangat rentan terhadap gangguan baik yang berasal dari alam maupun kegiatan antropogenik.

Laporan WCS (2019) menyebutkan persentase tutupan karang keras TNKJ tahun 2019 mengalami kenaikan di semua zonasi kecuali di zona pemanfaatan jika dibandingkan dengan tahun 2016. Persentase karang keras tertinggi terdapat di zona inti dan zona perlindungan. Sedangkan tutupan karang paling rendah terdapat di zona rehabilitasi dan zona pemanfaatan. Hal ini terjadi karena pada zona inti dan zona perlindungan merupakan kawasan tidak boleh melakukan aktifitas apapun di daerah tersebut sehingga tutupan karang keras tidak mengalami ancaman dari faktor antropologi seperti wisata ataupun penangkapan. Meskipun tutupan karang keras tahun 2019 mengalami kenaikan dibandingkan tahun 2016, namun dibandingkan dengan tahun 2012 dan 2013 persentase tutupan karang keras tahun 2019 masih lebih rendah. Meningkatnya persentase tutupan karang keras tahun 2019 menunjukkan adanya perbaikan kondisi terumbu karang dibandingkan tahun 2016.

\subsection{Input bagi Pengelolaan Kawasan Konservasi Taman Nasional Karimunjawa}

Hasil dari penilaian efektivitas pengelolaan kawasan konservasi TNKJ menggunakan pedoman METT, E-KKP3K dan COREMAP II-LIPI yang telah dilakukan sebelumnya mengungkap permasalahan yang menghambat tercapainya tujuan pengelolaan 
kawasan konservasi TNKJ. Analisis permasalahan tersebut menjadi cara baru yang dapat diterapkan dalam penyusunan struktur jaringan (model construction) ANP. Permasalahan yang telah teridentifikasi dibagi menjadi permasalahan ekologi, ekonomi, kelembagaan dan sosial.

\subsection{Prioritas Masalah Pengelolaan Kawasan Konservasi Taman Nasional Karimunjawa}

Berdasarkan hasil kombinasi seluruh aspek pada sub-kriteria permasalahan yang telah diolah menggunakan metode ANP, para informan kunci sepakat bahwa permasalahan prioritas pada pengelolaan kawasan konservasi TNKJ adalah implementasi sistem zonasi $(0,4093)$ yang merupakan permasalahan dalam kriteria kelembagaan. Masalah tersebut berkaitan dengan adanya pelanggaran penggunaan fungsi lahan pada tiap-tiap zona yang telah ditentukan, seperti zona yang seharusnya digunakan untuk ke-pentingan konservasi namun digunakan untuk lahan tambak tanpa izin, kegiatan pariwisata dan penangkapan ikan pada zona yang dilarang. Urutan prioritas permasalahan kedua adalah sampah (0,3805), semakin meningkatanya jumlah wisatawan maka semakin meningkat jumlah sampah pada kawasan konservasi. Hal tersebut berdampak secara langsung pada lingkungan. Urutan ketiga adalah belum optimalnya pengembangan usaha ekonomi masyarakat $(0,3706)$ yang menunjukkan tingginya ketergantungan masyarakat terhadap perikanan tangkap dan sektor wisata untuk memenuhi kebutuhan hidup seharihari. Sintesis nilai sub-kriteria permasalahan pengelolaan kawasan konservasi Taman Nasional Karimunjawa dapat dilihat pada Figure 5.

Pada setiap sub-kriteria memiliki prioritas permasalahan. Sub-kriteria pada permasalahan ekologi berupa ancaman penurunan jumlah spesies endemik $(0,3542)$ menjadi prioritas permasalahan ekologi. Pendataan spesies endemik TNKJ belum dilaksanakan secara optimal sehingga proses monitoring dan pengelolaan spesies endemik masih terbatas. Kemudian urutan permasalahan ekologi selanjutnya adalah degradasi ekosistem $(0,3240)$ yang disebabkan kegiatan antropogenik. Permasalahan ekologi selanjutnya adalah pengelolaan berbasis daya du-

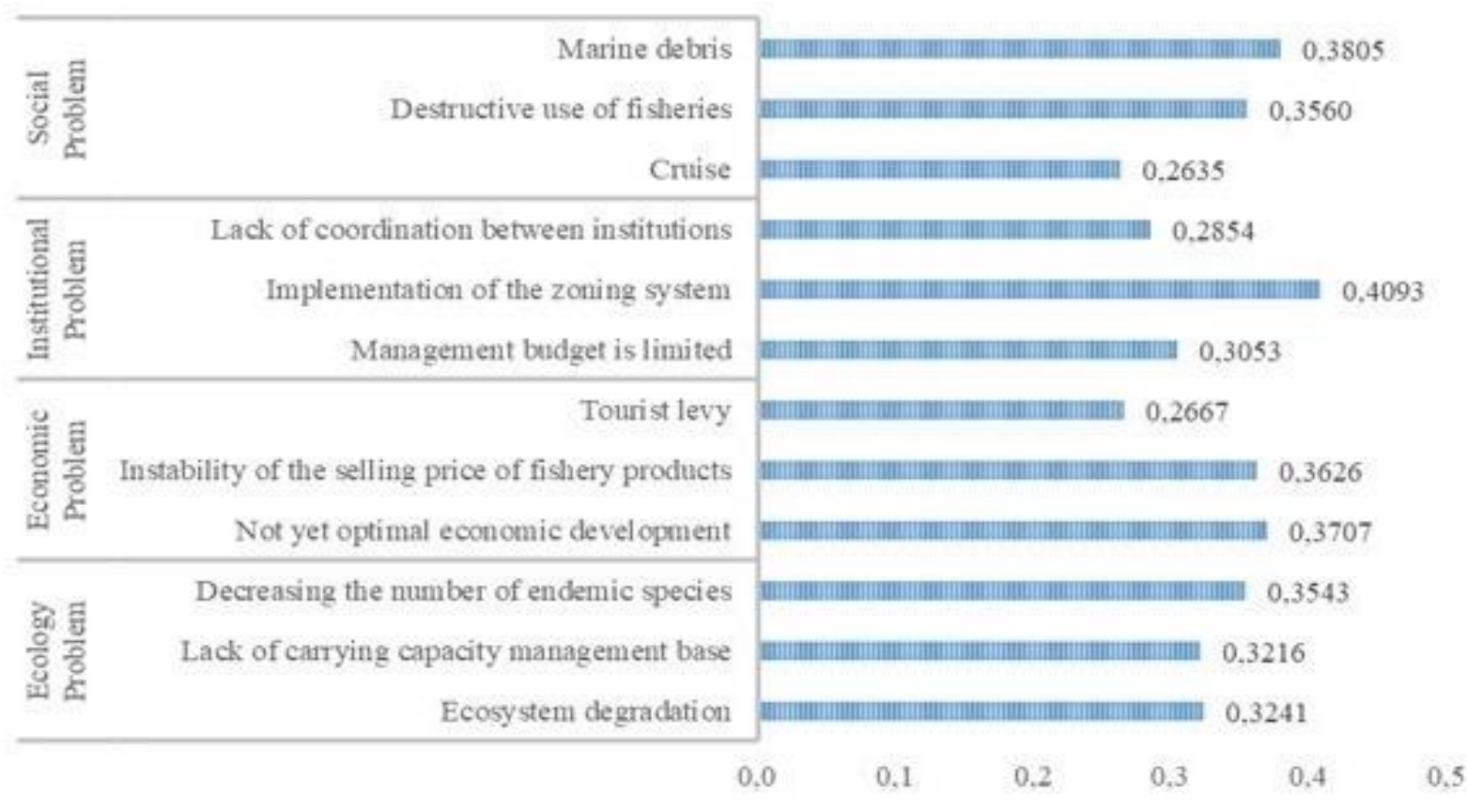

Figure 5. The main problem of the TNKJ conservation area management. 
kung $(0,3216)$ yang belum diterapkan dalam pengelolaan kawasan konservasi TNKJ.

Masalah pada sub-kriteria ekonomi yang menjadi prioritas adalah belum optimalnya pengembangan usaha ekonomi masyarakat $(0,3706)$, yang mana masyarakat masih sangat bergantung dengan sumber daya alam dan sektor wisata. Prioritas masalah ekonomi selanjutnya adalah ketidakstabilan harga jual hasil perikanan $(0,3625)$ yang disebabkan tidak berfungsinya Tempat Pelelangan Ikan (TPI). Retribusi wisatawan $(0,2667)$ yang masih terjadi akibat disharmoni pengelolaan antara Balai TNKJ dan Dinas Pariwisata dan Kebudayaan Kabupaten Jepara menjadi permasalahan dengan urutan ketiga.

Urutan permasalahan prioritas pada sub-kriteria kelembagaan adalah implementtasi sistem zonasi $(0,4093)$ yang juga merupakan permasalahan prioritas pengelolaan kawasan konservasi TNKJ. Urutan permasalahan kelembagaan selanjutnya adalah anggaran pengelolaan terbatas $(0,3052)$ yang menyebabkan terkendalanya aktivitas monitoring dan pengelolaan kawasan konservasi TNKJ. Permasalahan kelembagaan selanjutnya adalah kurangnya koordinasi antar lembaga $(0,2854)$.

Sub-kriteria sosial memiliki urutan permasalahan prioritas secara urut yakni masalah sampah $(0,3805)$, pemanfaatan perikanan yang merusak $(0,3559)$ oleh nelayan luar pulau Karimunjawa dan permasalahan pelayaran (0,2635). Hafsaridewi et al. (2018) menyatakan bahwa hingga 2017, sistem zonasi telah meninggalkan masalah seperti biota dan kondisi ekosistem yang rusak, serta belum adanya integrasi antara manajemen sumber daya dan peraturan.

\subsection{Solusi Permasalahan Pengelolaan Kawasan Konservasi Taman Nasional Karimunjawa}

Peningkatan efektivitas pengelolaan kawasan konservasi TNKJ dapat dilakukan dengan penyusunan dan implementasi strategi pengelolaan kawasan konservasi. Sintesis sub-kriteria solusi untuk melihat kontri- busi masing-masing elemen solusi pada setiap aspek dalam upaya menyusun prioritas pengelolaan kawasan konservasi TNKJ secara keseluruhan dikombinasikan pada Figure 6.

Hasil kombinasi seluruh aspek pada sub-kriteria solusi, para informan kunci sepakat bahwa permasalahan prioritas pada pengelolaan kawasan konservasi TNKJ adalah penyadaran masyarakat dan wisatawan terhadap bahaya sampah dan kerusakan lingkungan $(0,4256)$ yang terdapat pada subkriteria sosial. Hal yang menjadi penentu keberhasilan suatu program adalah jika sudah terdapat kesadaran pengguna kawasan tersebut. Semakin tinggi tingkat kesadaran masyarakat dan wisatawan, maka semakin rendah tingkat pelanggaran dan kerusakan ekosistem akibat aktivitas manusia. Solusi kedua terdapat pada sub-kriteria ekologi yakni perbaikan fungsi ekosistem $(0,3963)$ yang dapat dilakukan salah satunya melalui teknologi terumbu karang buatan dan transplantasi. Hal tersebut dapat membantu perbaikan fungsi spawning, nursery, dan feeding ground ekosistem terumbu karang.

Solusi prioritas ketiga yang dapat dilakukan adalah dengan penyadaran masyarakat tentang pemanfaatan berkelanjutan $(0,3920)$ yang masuk dalam sub-kriteria solusi kelembagaan. Hal ini dilakukan untuk menjaga jumlah tangkapan dengan cara penangkapan yang ramah lingkungan sehingga kondisi ekosistem tetap terjaga. Penyadaran masyarakat tentang pemanfaatan yang berkelanjutan dapat dilakukan oleh instansi terkait berupa sosialisasi dan aksi nyata lain.

Pada setiap sub-kriteria memiliki prioritas solusi. Sub-kriteria pada solusi ekologi secara urut adalah perbaikan fungsi ekosistem (0,3963), kemudian pembaharuan sistem pengelolaan $(0,3196)$. Sistem yang sudah terlaksana akan terlihat adanya kekurangan pada pelaksanaannya sehingga dapat dibuat pembaharuan sistem pengelolaan berkelanjutan untuk kawasan konservasi tersebut. Solusi ketiga dari subkriteria ekologi adalah penangkaran spesies 


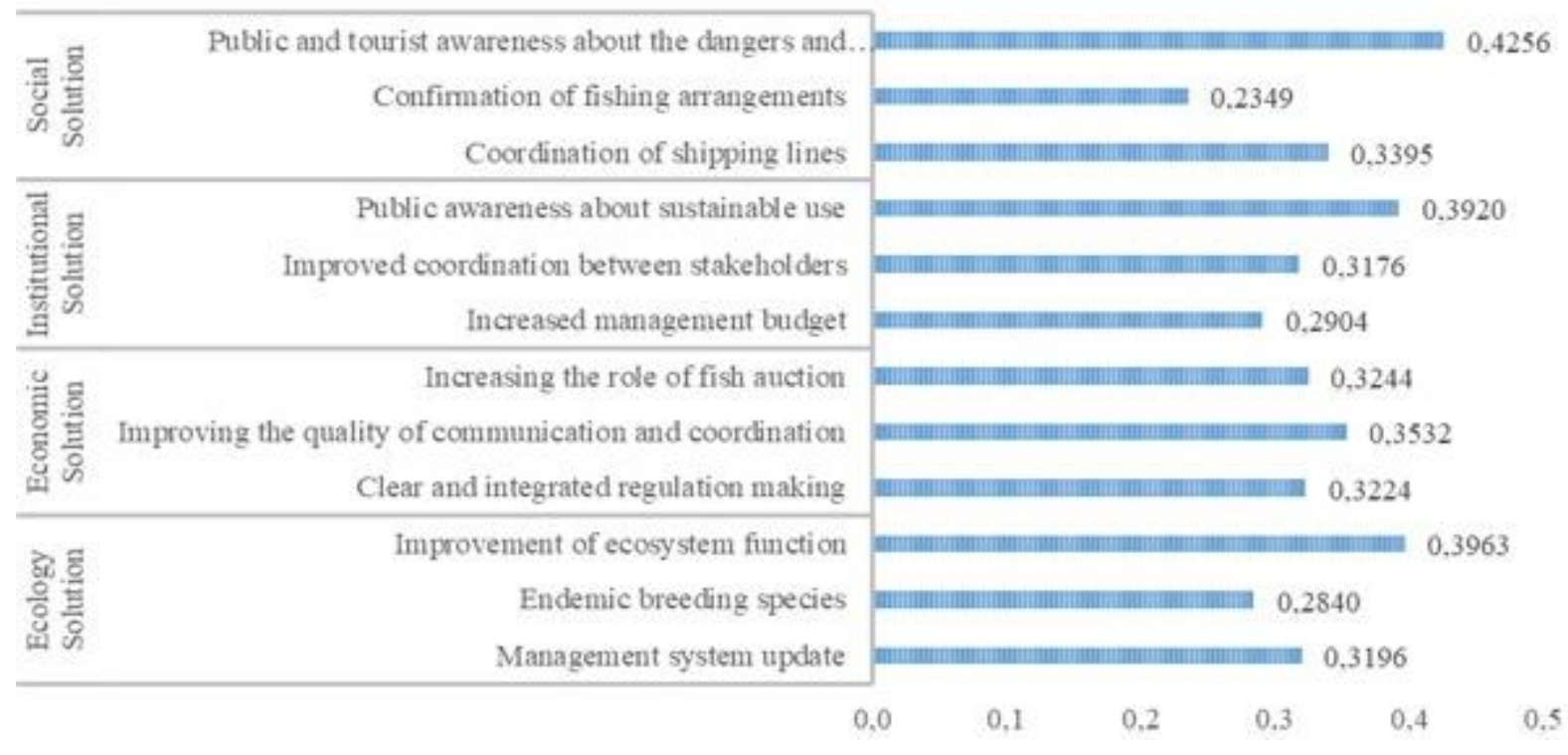

Figure 6. The Main Solution of The TNKJ Conservation Area Management.

endemik yang dapat dilakukan untuk melindungi spesies asli dan ekosistem pada kawasan konservasi TNKJ $(0,2840)$.

Pada sub-kriteria ekonomi, solusi prioritas pertama adalah peningkatan kualitas koordinasi dan komunikasi $(0,3531)$ oleh para pihak yang berkepentingan dalam pengelolaan kawasan konservasi TNKJ. Solusi ekonomi selanjutnya adalah peningkatan peran TPI $(0,3244)$. Hal ini dapat dilakukan mengingat TPI dikawasan konservasi TNKJ belum beroperasi dengan optimal. Urutan solusi ekonomi selanjutnya adalah pembuatan peraturan yang jelas dan terintegrasi $(0,3224)$ sehingga peraturan dapat dimplementasi dengan baik.

Solusi pada sub-kriteria kelembagaan memiliki urutan prioritas penyadaran masyarakat tentang pemanfaatan berkelanjutan (0,3920). Urutan solusi kelembagaan selanjutnya adalah peningkatan koordinasi antar stakeholder $(0,3175)$ yang dapat dilakukan untuk menghindari konflik pengelolaan kawasan konservasi TNKJ, kemudian peningkatan anggaran pengelolaan $(0,2904)$ sesuai dengan kebutuhan pengelolaan kawasan. Cukupnya anggaran pengelolaan akan memengaruhi kinerja pengelolaan kawasan konservasi.

Sub-kriteria sosial memiliki prioritas solusi dari permasalahan yang telah dipaparkan, yakni penyadaran masyarakat dan wisatawan terhadap bahaya sampah dan kerusakan lingkungan $(0,4256)$. Urutan solusi sosial selanjutnya adalah koordinasi jalur pelayaran $(0,3394)$ yang dapat digunakan untuk mengatur jumlah pengunjung saat masuk ke kawasan konservasi TNKJ. Urutan solusi sosial ketiga adalah penegasan pengaturan penangkapan ikan $(0,2348)$ untuk mengurangi potensi kerusakan ekosistem akibat penangkapan ikan dengan cara merusak dan penangkapan ikan dengan alat tangkap yang tidak diperbolehkan.

Berdasarkan hasil sintesis kriteria masalah dan solusi dari pendapat informan kunci dengan analisis ANP, dapat diketahui nilai Kendall's Coefficient of Concordance (W) sebesar $73,48 \%$ (>70\%). Nilai W tersebut berarti responden memiliki kesesuaian yang cukup besar terhadap prioritas permasalahan dan solusi pengelolaan kawasan konservasi TNKJ. Adanya penentuan prioritas permasalahan dan solusi bagi pengelolaan kawasan konservasi TNKJ dapat memudahkan pihak pengelola dalam pembuatan strategi dalam pelaksanaan rencana strategis Balai TNKJ.

Kawasan konservasi perairan dengan pengelolaan secara efektif dapat memiliki 
banyak manfaat, diantaranya dapat meningkatkan kelimpahan, ukuran, keanekaragaman dan biomassa ikan (Halpern, 2003). Selain itu, kawasan konservasi dapat memberikan ruang spill over ikan dari dalam kawasan konservasi keluar kawasan konservasi (Chapman \& Kramer, 1999), meningkatkan stok perikanan dengan cara penyebaran larva dari dalam kawasan konservasi (Harrison et al., 2012) dan meningkatkan daya lenting terumbu karang dari perubahan iklim (Mumby et al., 2007).

\section{KESIMPULAN}

Penggunaan pedoman yang tepat bagi pengelolaan kawasan konservasi dapat memudahkan pengelola kawasan untuk melihat kelebihan dan kekurangan pada setiap aspek pengelolaan kawasan konservasi, sehingga dapat ditemukan permasalahan yang perlu untuk ditangani demi peningkatan efektivitas pengelolaan kawasan konservasi. Penilaian efektivitas kawasan konservasi TNKJ dikatakan sangat efektif menurut pedoman METT dengan hasil penilaian sebesar $78 \%$, efektif menurut pedoman COREMAP II-LIPI dengan hasil penilaian $71 \%$ dan merupakan kawasan konservasi yang dikelola secara minimum menurut pedoman E-KKP3K dengan status hijau.

ANP dapat digunakan untuk mengidentifikasi prioritas dalam penyusunan strategi pengelolaan kawasan konservasi TNKJ yang efektif dengan integrasi antara empat elemen cluster (ekologi, sosial, ekonomi dan kelembagaan). Strategi peningkatan efektivitas pengelolaan kawasan konservasi TNKJ dapat dicapai dengan fokus prioritas strategi yakni: (1) Penyadaran masyarakat dan wisatawan terhadap bahaya sampah dan kerusakan lingkungan (0,4256); (2) Perbaikan fungsi ekosistem (0,3963); (3) Penyadaran masyarakat tentang pemanfaatan berkelanjutan (0,3920). Strategi peningkatan efektivitas pengelolaan kawasan konservasi TNKJ dapat tercapai apabila terdapat koor-dinasi yang baik antara semua pihak demi mewujudkan pengelolaan kawasan konservasi yang lebih efektif dan memberikan manfaat bagi masyarakat secara berkelanjutan.

\section{UCAPAN TERIMA KASIH}

Terima kasih penulis ucapkan kepada Direktorat Jenderal Konservasi Sumber Daya Alam dan Ekosistem Kementerian Lingkungan hidup dan Kehutanan yang telah mengeluarkan pedoman penilaian METT (Management Effectiveness Tracking Tool). Direktorat Jenderal Pengelolaan Ruang Laut Kementerian Kelautan dan Perikanan yang telah mengeluarkan Pedoman Teknis Evaluasi Efektivitas Pengelolaan Kawasan Konservasi Perairan, Pesisir dan Pulau-Pulau Kecil (E-KKP3K). COREMAP II-LIPI yang telah mengeluarkan Panduan Evaluasi Efektivitas Pengelolaan untuk Kawasan Konservasi Laut di Indonesia, serta Balai Taman Nasional Karimunjawa.

\section{DAFTAR PUSTAKA}

Ascarya, 2010. The development of islamic financial system in indonesia and the way forward. Occasional paper No. OP/10/02. Bank Indonesia. Jakarta. 56-57 pp.

Bengen, G. 2001. Ekosistem dan sumberdaya pesisir dan laut serta sengelolaan secara terpadu dan berkelanjutan. Prosiding pelatihan pengelolaan wilayah pesisir terpadu, Pusat Kajian Sumberdaya Pesisir dan Lautan (PKSPL), Bogor, 29 Oktober - 3 November 2001. 28-55 pp.

Cahyani, W.S., I. Setyobudiandi, \& R. Affandy. 2018. Kondisi dan status keberlanjutan ekosistem terumbu karang di kawasan konservasi Perairan Pulo Pasi Gusung, Selayar. J. Ilmu dan Teknologi Kelautan Tropis. 10(1): 153-166. https://doi.org/10.29244/jitkt.v10i1.2 1672 
Chapman, M.R. \& D.L. Kramer. 1999. Gradients in coral reef fish density and size across the barbados marine reserve boundary: effects of reserve protection and habitat characteristics. Marine Ecology Progress Series, 181(1): 81-96. https://www.intres.com/articles/meps/181/m181p081. pdf

Firdaus, M. \& Y.D. Sari. 2010. Pemanfaatan dan pengelolaan kawasan konservasi sumberdaya perikanan (Studi kasus di Lubuk Larangan Lubuk Panjang Barung-Barung Balantai, Kabupaten Pesisir Selatan, Sumatera Barat). J. Bijak dan Riset Sosek KP, 5(1): 1-18. http://doi.org/10.15578/jsekp.v5i1.57 88

Hafsaridewi, R., Sulistiono, A. Fahrudin, D. Sutrisno, \& S. Koeshendrajana. 2018. Manajemen sumberdaya di Pulau Karimunjawa, Jawa Tengah, Indonesia menggunakan pendekatan DPSIR. AES Bioflux, 10(1): 1-16. http://www.aes.bioflux.com.ro/docs/2 018.7-22.pdf

Halpern, B.S. 2003. The impact of marine reserves: do reserves work and does reserve size matter?. Ecological applications, 13(1): 117-137. https://doi.org/10.1890/10510761(2003)013[0117:TIOMRD]2.0.C $\mathrm{O} ; 2$

Hargreaves-Allen, V., S. Mourato, \& E.J. Milner-Gulland. 2017. Drivers of coral reef marine protected area performance. PLOS ONE, 12(6): 1-21. https://doi.org/10.1371/journal.pone.0 179394

Harrison, H.B., D.H Williamson, \& R.D Evans. 2012. Larval export from marine reserves and the recruitment benefit for fish and fisheries. Current Biology, 22(1): 1023-1028. https://doi.org/10.1016/j.cub.2012.04. 008

Hora, S.C. 2009. Expert judgment in risk analysis. Non-Published Research
Reports. $11 \mathrm{p}$.

Juliyanto, E., Zairion, M. Krisanti, \& H.A. Susanto. 2019. Analisis prioritas pengelolaan kawasan konservasi perairan Pulau Ay-Rhun, Provinsi Maluku. J. Ilmu dan Teknologi Kelautan Tropis, 11(3): 721-733. http://doi.org/10.29244/jitkt.v11i1.25 763

Kementerian Koordinator Bidang Kemaritiman. 2017. Kebijakan pengelolaan kawasan konservasi laut di Indonesia. Asisten Deputi Lingkungan dan Kebencanaan Maritim Deputi Bidang Koordinasi Sumber Daya Alam dan Jasa. Jakarta. $174 \mathrm{p}$.

Kementerian Kelautan dan Perikanan (KKP). 2013. Pedoman teknis evaluasi efektivitas pengelolaan kawasan konservasi perairan, pesisir dan pulau-pulau kecil (E-KKP3K). Direktorat Jenderal Kelautan, Pesisir dan Pulau-Pulau Kecil, Direktorat Konservasi Kawasan dan Jenis Ikan. Jakarta. 66 p.

Kementerian Lingkungan Hidup dan Kehutanan (KLHK). 2015. Pedoman penilaian efektivitas pengelolaan kawasan konservasi di Indonesia. Direktorat Kawasan Konservasi, Direktorat Jenderal Konservasi Sumberdaya Alam dan Ekosistem. Jakarta. 110 p.

Kerlingeer, F. \& H.B. Lee. 2000. Foundation of behaviour research. Harcourt College Publishers. California. $82 \mathrm{p}$.

Leenhardt, P., N. Low, N. Pascal, F. Micheli, \& J. Claudet. 2015. The Role of Marine Protected Areas in Providing Ecosystem Services. Aquatic Funcitonal Biodiversity-An Ecological and Evolutionary Perspective, 9(1): 211-239. http://doi.org/10.1016/B978-0-12417015-5.00009-8

Mittermeier, R.A., I.A. Bowles, \& R.B Cavalcanti. 1995. A participatory 
approach to biodiversity conservation: the regional priority setting workshop. Conservation International. Washington. $16 \mathrm{p}$.

Mumby, P.J., A.R Harborne, J. Williams, C.V Kappel, D.R Brumbaugh, F. Micheli, K.E Holmes, C.P Dahlgreen, C.B Paris, \& P.G Blackwell. 2007. Trophic Cascade Facilitates Coral Recruitment in a Marine Reserve. PNAS, 104(20): 8362-8367. https://doi.org/10.1073/pnas.0702602 104

Pelletier, D., J.A. Garcia Charton, J. Ferraris, G. David, O. Thebaud, Y. Letourneur, J. Claudet, M. Amand, M. Kulbicki, \& R. Galzin. 2005. Designing indicators of assessing the effects of marine potected areas on coral reef ecosystems: a multidisciplinary standpoint. Aquatic Living Resources, 18(1): 15-33. https://doi.org/10.1051/alr:2005011

Pitcher, T.J. 1999. Rapfish, a rapid appraisal technique for fisheries and its applications to the code of conduct for responsible fisheries. FAO Fisheries Circular. Canada. $52 \mathrm{p}$.

Saaty, T.L. 1999. Theory and applications of the analytic network process: decision making with benefit, opportunities, costs, and risks. RWS Publications. Pittsburgh. 278 p.

Susetiono, P. Swasti, Supono, \& I.W.E Dharmawan. 2010. Penyusunan panduan evaluasi efektivitas pengelolaan untuk kawasan konservasi laut di Indonsia. CRITC COREMAP II-LIPI. Jakarta. 92 p.

Received : 5 February 2020

Reviewed : 2 March 2020

Accepted : 16 July 2020 
